\title{
Using Kaolinitic Clay for Preparation of a Hydrotalcite-Like Compound
}

\author{
Khaled Hosni*, Ezzeddine Srasra \\ Centre National des recherches en Sciences des Matériaux, Pôle technologique de Borj Cedria, Nabeul, Tunisia. \\ Email: hosnikhaled@gmail.com
}

Received December 24 ${ }^{\text {th }}, 2010$; revised March 21 ${ }^{\text {st }}, 2011$; accepted May $18^{\text {th }}, 2011$.

\begin{abstract}
In this study, $\mathrm{Mg}-\mathrm{Al}-\mathrm{CO}_{3}$ hydrotalcite was synthesized from a kaolinite as natural source aluminium using two simple methods. The first method uses the kaolinite in natural solid state, the second method use the filtrate of the kaolinite after dissolution by acidic solutions. The structure of the materials was characterized by X-ray diffraction, Fourier transform infrared spectroscopy, differential scanning calorimetry (DSC) and Brunauer, Emmett, and Teller (BET) measurements.
\end{abstract}

Keywords: Hydrotalcite, Kaolinite, Layered Compound, XRD, Memory Effect

\section{Introduction}

A wide range of compositions are possible for synthetic hydrotalcites based on the general formula $\left[\mathrm{M}_{1-\mathrm{y}}^{\mathrm{II}} \mathrm{L}_{\mathrm{y}}^{\mathrm{III}}(\mathrm{OH})_{2}\right]^{\mathrm{y}+}\left[\mathrm{X}^{\mathrm{n}-}\right]_{\mathrm{y} / \mathrm{n}}\left[\mathrm{H}_{2} \mathrm{O}\right]_{\mathrm{z}}$, where $\mathrm{M}^{\mathrm{II}}$ and $\mathrm{M}^{\mathrm{III}}$ are the divalent and trivalent cations in the octahedral positions within the hydroxide layers. The value y can have a range between 0.17 and 0.33 , while $X^{n-}$ is an interlayer anion with a negative charge $\mathrm{n}^{-}[1,2]$, and $\mathrm{z}$ is the number of water molecules. Many anions or anionic complexes, both organic and inorganic, can be incorporated into the hydrotalcite structure. The hydrotalcite can be abbreviated as $\left[\mathrm{M}^{\mathrm{II}}-\mathrm{M}^{\mathrm{III}}-\mathrm{X}\right]$, where, $\mathrm{M}^{\mathrm{II}}=\mathrm{Mg}^{2+}, \mathrm{Zn}^{2+}, \mathrm{Cu}^{2+}$, $\mathrm{Ca}^{2+}, \mathrm{Mn}^{2+} ; \mathrm{M}^{\mathrm{III}}=\mathrm{Al}^{3+}, \mathrm{Cr}^{3+}, \mathrm{Fe}^{3+}, \cdots ;$ and $\mathrm{X}^{\mathrm{n}-}=\mathrm{Cl}^{-}$, $\mathrm{NO}^{3-}, \mathrm{CO}^{3-}, \mathrm{PO}_{4}^{3-}$, etc.

Hydrotalcite-like compounds, also called layered double hydroxides (LDHs), have received considerable attention in recent years owing to their layered structure and high anion-exchange capacity [3], which makes them potential materials for technical applications in various domains [4]. These materials have been investigated as solid ionic conductors [5] and sensors [6]. Layered double-metal hydroxides are, or may be used as, catalysts $[4,7]$, photo-catalysts, catalyst supports [8], adsorbents $[9,10]$, anion exchangers [11], medicines [12,13] and bonding materials. The reason for the potential application of hydrotalcites as catalysts rests with their ability to make mixed metal oxides at the atomic level, rather than the particle level. Such mixed metal oxides are formed through the thermal decomposition of the hydrotalcite
[14]. Also, LDH materials have been extensively studied in terms of their thermal evolution $[15,16]$, textural properties [16], and the formation of nanosized metal particles [17] as well as for environmental purposes [18].

The present study reports simplified method to synthesize the carbonate forms of layered double hydroxides from a natural source of trivalent cations. $\mathrm{Mg}-\mathrm{Al}-\mathrm{CO}_{3}$ hydrotalcite-like layered compounds have been synthesized with $\mathrm{Mg} / \mathrm{Al}$ ratios of 3 by a mechanochemical method using kaolinite in solid state and by coprecipitation using the under product of the acidic dissolution of the kaolinite.

\section{Experimental}

\subsection{Material Preparation}

The Mg-Al- $\mathrm{CO}_{3}$ hydrotalcite-like layered compounds has been synthesized by two simple methods using kaolinite as a natural source of trivalent cations and an aqueous solution of $\mathrm{Na}_{2} \mathrm{CO}_{3}$ as the precipitant.

\section{Method 1}

The sample was synthesized by crushing kaolinite with the magnesium nitrate hexahydrate (their amounts were so as to have the desired $\mathrm{Mg}^{2+} / \mathrm{Al}^{3+}$ molar ratio), followed by heating at $500^{\circ} \mathrm{C}$ for 4 hours. The product obtained was dispersed under constant stirring in an aqueous solution containing $\mathrm{Na}_{2} \mathrm{CO}_{3}(100 \mathrm{~mL})$. The $\mathrm{pH}$ of the dispersion was maintained constant at $10 \pm 0.1$ by adding $\mathrm{NaOH}$ or $\mathrm{HNO}_{3}$ when necessary. The slurry was subse- 
quently agitated at room temperature for $24 \mathrm{~h}$, and then aged at $150^{\circ} \mathrm{C}$ for $24 \mathrm{~h}$. The resulting products were collected by centrifugal separation and washed thoroughly with deionised water to eliminate excess $\mathrm{Na}^{+}$followed by drying overnight at room temperature.

The samples were identified as $\left[K_{s d} 3 P 10-T 150\right]$, where $K_{s d}$ represents the trivalent cation source (kaolinite) used to prepare the materials and " $s d$ " represents the solid state. For example, $K_{s d} 3 P 10-T 150$ stands for the product prepared with kaolinite in solid state, a $\mathrm{Mg} / \mathrm{Al}$ ratio of 3, an aging temperature of $150^{\circ} \mathrm{C}$, and a $\mathrm{pH}$ of synthesis of 10 .

\section{Method 2}

The sample was synthesized using as aqueous solution of $\mathrm{Na}_{2} \mathrm{CO}_{3}$ as precipitant. The solutions containing $\mathrm{Mg}\left(\mathrm{NO}_{3}\right)_{2} \cdot 6 \mathrm{H}_{2} \mathrm{O}$ and $\mathrm{Al}^{3+}$, cation resulting from dissolution of the purified kaolinite by acidic attack, (their concentration varied so as to have the $\mathrm{Mg} / \mathrm{Al}$ molar ratio of 3) were added dropwise to the aqueous solutions of $\mathrm{Na}_{2} \mathrm{CO}_{3}$ with vigorous stirring. The $\mathrm{pH}$ of the dispersion was maintained constant at $10 \pm 0.1$ by adding $\mathrm{NaOH}(10 \%)$. The slurry was subsequently agitated at room temperature for tree day. The resulting products were collected by centrifugal separation and washed thoroughly with deionised water to eliminate excess $\mathrm{Na}^{+}$followed by drying overnight at room temperature.

The samples were identified as $\left[K_{\text {liq }} 3 P 10\right]$, where $K_{\text {liq }}$ represents the trivalent cation source (kaolinite) used to prepare the materials and "liq" represents its liquid state. For example, $K_{\text {liq }} 3 P 10$ stands for the product prepared with kaolinite in liquid state, an $\mathrm{Mg} / \mathrm{Al}$ ratio of 3 and a $\mathrm{pH}$ of synthesis of 10 .

\subsection{Characterization of Materials}

The dried precipitates were characterized by X-ray diffraction (XRD) in order to determine the species present and their degree of crystallinity. Diffractograms were obtained by using a 'PANalytical X'Pert HighScore Plus' diffractometer using monochromated $\mathrm{CuK} \alpha$ radiation. Nitrogen adsorption measurements were performed at $-196^{\circ} \mathrm{C}$ with an Autosorb-1 unit (Quantachrome, USA) for the determination of sample textural properties using the multipoint Brunaner-Emmet-Teller (BET) method. The samples were out gassed at $120^{\circ} \mathrm{C}$ under a vacuum at $10^{-3} \mathrm{mmHg}$ for $3.5 \mathrm{~h}$. Fourier-transformed infrared (FT-IR) spectra were recorded as $\mathrm{KBr}$ pellets using a PerkinElmer FT-IR (model 783) instrument. $\mathrm{KBr}$ pellets were prepared by mixing $5 \mathrm{wt} \%$ anionic clay with $95 \mathrm{wt} \%$ $\mathrm{KBr}$ and pressing. Differential scanning calorimeter (DSC) experiments were performed with Mettler Toledeo DSC-823 type thermal analyzer at heating rates of $20.0^{\circ} \mathrm{C} \cdot \mathrm{min}^{-1}$.

\section{Results and Discussion}

\subsection{Characterization of the Clay}

The sample selected for this study is Tabarka clay (Tunisian clay).

\subsubsection{X-Ray Diffraction}

The nature of the impurities was determined by examining the crude samples. Quartz (reflection at $3.35 \AA$ ) is the major impurity. The diffractogramme of purified sample (Figure 1(a)) show the reflections at $\mathrm{d}=7.21 \AA$ and $10.05 \AA$ characteristic of the kaolinite and illite respectively [19].

In Figure 1(b) is shown the powder XRD pattern of the mixture of kaolinitic clay and the magnesium nitrate after heating at $500^{\circ} \mathrm{C}$. Owing to the fact of the absence of the peak corresponding of the d-spacing of 7.21 $\AA$ and attributed of the kaolin in the XRD pattern of the product shows that the structure of the original clay is completely destroyed and indicates metal oxide peaks, suggesting an almost total decomposition of the original clay. This observation is consistent with the result given by the study of the thermal stability for the clay sample. Indeed, heating the sample clay in air above $500^{\circ} \mathrm{C}$ (Figure 2(b)), the peak at $7.21 \AA$ disappears while the peak characteristic of illite $(\mathrm{d}=10.05 \AA)$ persists. The treatment with ethylene glycol does not have any effect (Figure 2(c)).

\subsubsection{Infrared Spectra}

Figure 3(a) shows the Infrared spectra of purified clay over the frequency range of $4000-400 \mathrm{~cm}^{-1}$. The figure shows that purified sample contain quartz $\left(800 \mathrm{~cm}^{-1}\right)$. The spectrum exhibited the characteristic band at 3697 $\mathrm{cm}^{-1}$ confirming the dominant presence of kaolinite. The band, at $1637 \mathrm{~cm}^{-1}$ and $3450 \mathrm{~cm}^{-1}$ corresponds to the bonding modes of absorbed and zeolitic water.

\subsubsection{Chemical Composition}

The purified clay sample was attacked by a mixture of three acids $\left(\mathrm{HCl}, \mathrm{H}_{2} \mathrm{SO}_{4}\right.$, and $\left.\mathrm{HNO}_{3}\right)$. All elements were dissolved into solution expect for the $\mathrm{Si}$ which was determined by gravimetric method analysis. The Al and Fe were assayed by atomic absorption spectrophotometer (AAS Vario 6). The chemical composition data (Table 1) indicates that the percentage of $\mathrm{Al}_{2} \mathrm{O}_{3}$ is $30 \%$ confirming that sample is kaolinitic clay

\subsection{Characterization of the $K_{l i q} 3 P 10-L D H$ and $K_{s d} 3 P 10-L D H$}

\subsubsection{Powder X-Ray Diffraction}

Figure 1 shows the XRD patterns for the precipitates obtained by method 1 and method 2 . It is shown that the $K_{s d} 3 P 10-L D H$ and $K_{\text {liq }} 3 P 10-L D H$ samples patterns (Figures $\mathbf{1}(\mathbf{c})$ and $\mathbf{1 ( d ) )}$ were comparable to that pattern of 


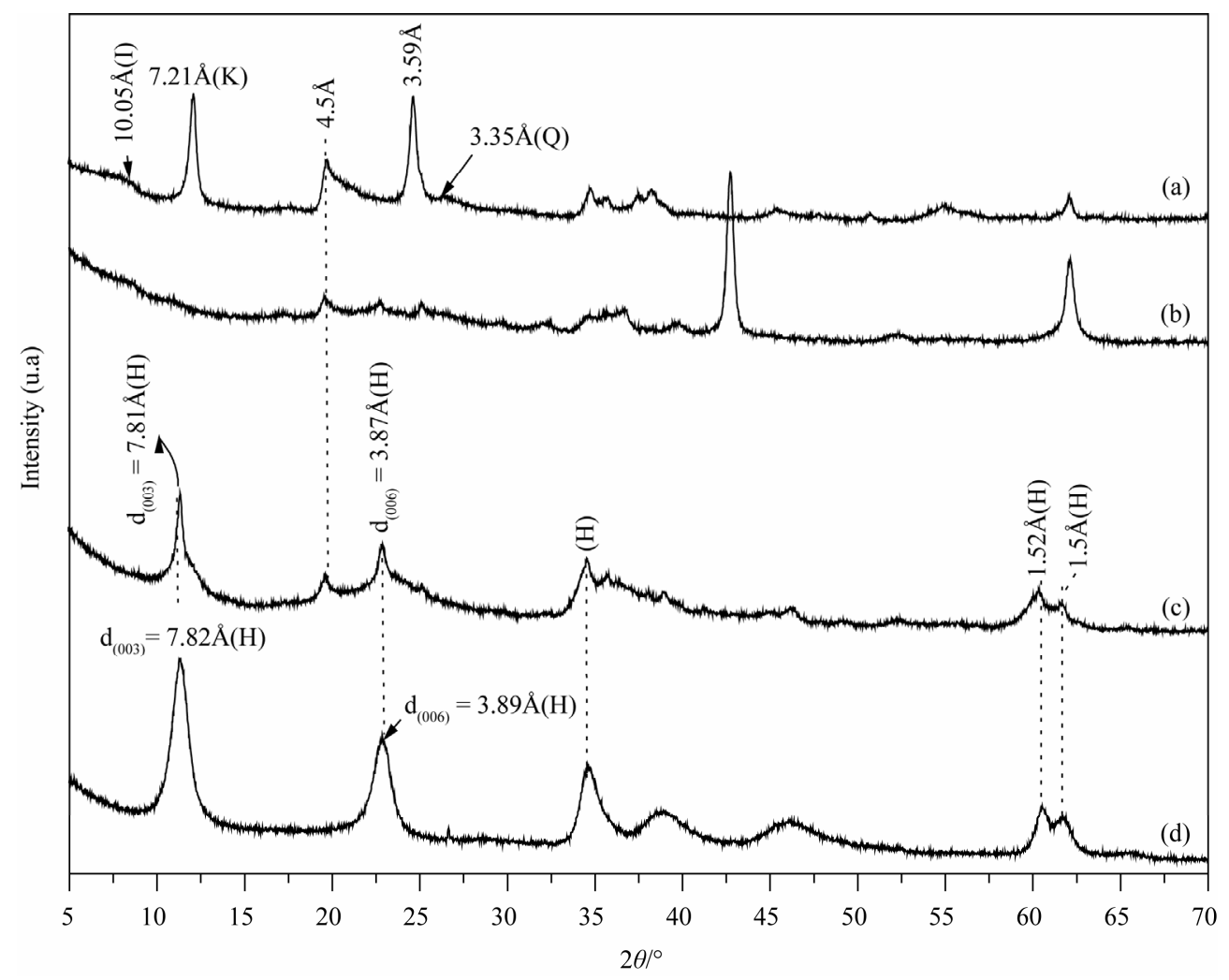

Figure 1. X-ray patterns of clay sample: (a) purified clay; (b) Clay $+\mathrm{Mg}\left(\mathrm{NO}_{3}\right) \cdot 6 \mathrm{H}_{2} \mathrm{O}$ and heated at $500^{\circ} \mathrm{C}$; (c) $\mathrm{K}_{\mathrm{sd}} 3 \mathrm{P10}-\mathrm{T150}$; (d) $K_{\text {liq }} 3$ P10. [(K) Kaolinite, (I) Illite, (Q) Quartz, (H) hydrotalcite.

Table 1. The chemical composition of the purified clay.

\begin{tabular}{ccccccccc}
\hline$\%$ & $\mathrm{SiO}_{2}$ & $\mathrm{Al}_{2} \mathrm{O}_{3}$ & $\mathrm{Fe}_{2} \mathrm{O}_{3}$ & $\mathrm{CaO}$ & $\mathrm{Na}_{2} \mathrm{O}$ & $\mathrm{MgO}$ & $\mathrm{K}_{2} \mathrm{O}$ & Ignition loss \\
\hline Clay & 48.75 & 30 & 3.39 & 0.33 & 1.45 & 0.07 & 1.95 & 13.93 \\
\hline
\end{tabular}

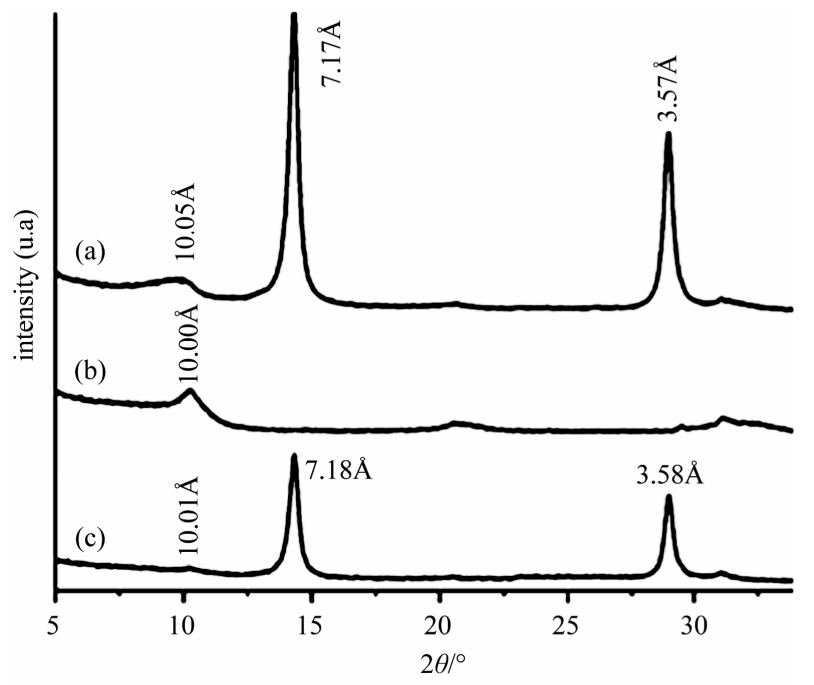

Figure 2. X-ray patterns of: (a) oriented crude simple; (b), oriented heated sample; (c) oriented sample treated with glycol. the sample prepared by the conventional method. The $K_{\text {liq }} 3 P 10-L D H$ sample showed a layered structure as observed from the peaks at 7.82, 3.89 and $2.61 \AA$, corresponding to planes (003), (006) and (009) for a layered hydrotalcite-like material, respectively [20]. The $K_{s d} 3 P 10-L D H$ sample display very weak and broad peaks at a $2 \theta$ value of $11^{\circ}$ compared to the sample prepared by coprecipitation at the same conditions $(\mathrm{pH}=10$ and $\left.\mathrm{Mg}^{2+} / \mathrm{Al}^{3+}=3\right) . K_{s d} 3 P 10-L D H$ shows a structure different from the previous samples; it was an ill-defined hydrotalcite contaminated with argillaceous phase $(\mathrm{d}=4.5 \AA)$.

\subsubsection{IR Spectroscopy}

The FT-IR spectra of the $K_{s d} 3 P 10-L D H$ and $K_{\text {liq }} 3 P 10-$ $L D H$ hydrotalcite are presented in Figures 3(b) and 3(c). It shows a broad band around $3470 \mathrm{~cm}^{-1}$ due to the stretching mode of the structural $-\mathrm{OH}$ groups in the metal hydroxide However, a small shoulder at 2900 $3000 \mathrm{~cm}^{-1}$ suggests the presence of a second type of $-\mathrm{OH}$ stretching vibration (possibly due to hydrogen bonding 


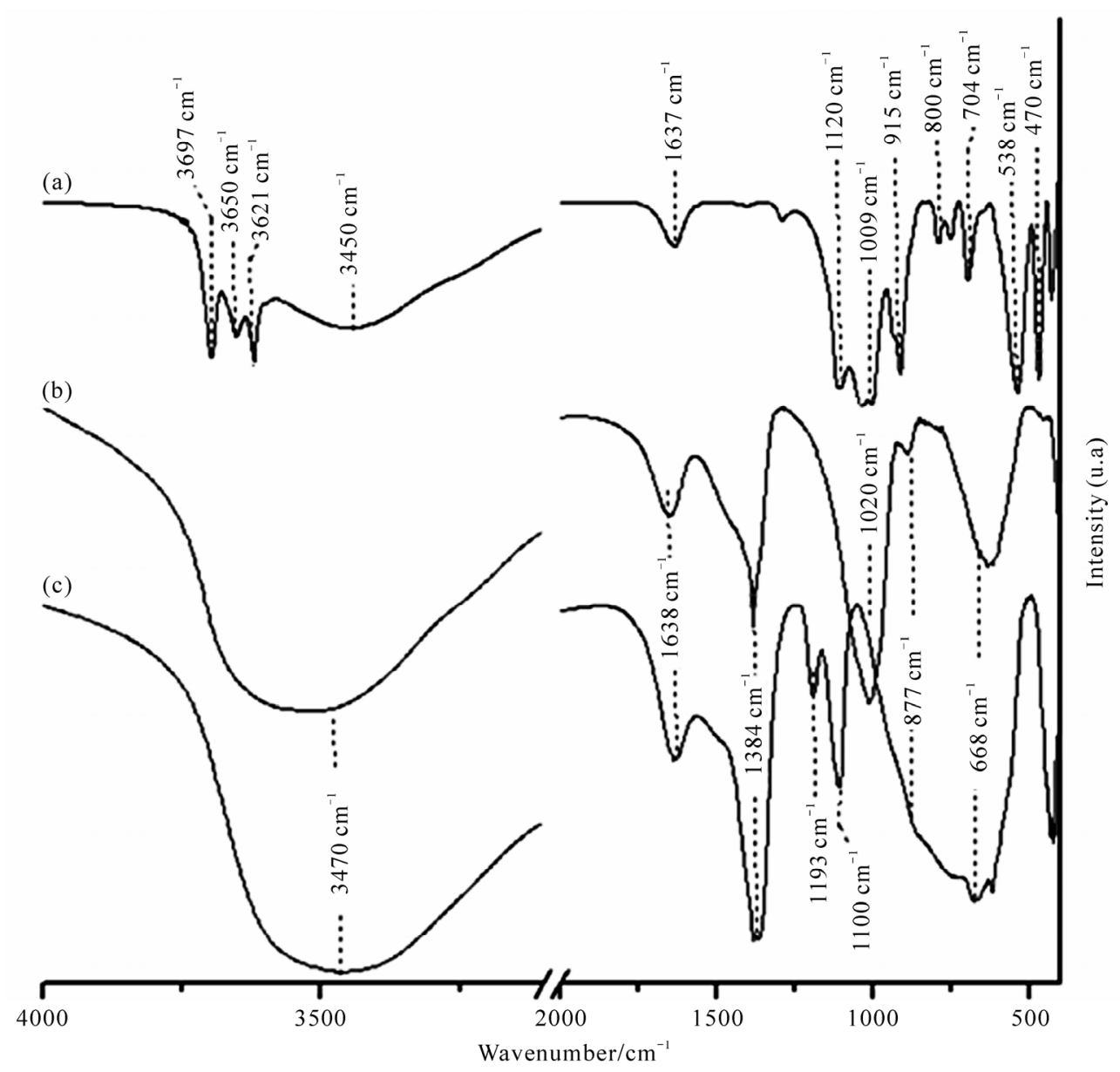

Figure 3. Infrared spectra of: (a) purified clay; (b) $K_{s d} 3 P 10-T 150$; (c) $K_{\text {liq }} 3 P 10$.

with carbonate in the interlayer spacing [21].

The two spectra show:

1) A shoulder at $1638 \mathrm{~cm}^{-1}$ is ascribed to the bending mode of the interlayer water molecules [22].

2) The three characteristic bands of carbonate in hydrotalcite at around $1384 \mathrm{~cm}^{-1}\left(v_{3}\right), 877 \mathrm{~cm}^{-1}\left(v_{2}\right)$ and $\sim 1020 \mathrm{~cm}^{-1}\left(v_{1}\right)[23,24]$.

3) The bands around 420 and $668 \mathrm{~cm}^{-1}$, which are ascribed to the bending mode $\mathrm{Al}-\mathrm{O}$ and $\mathrm{Mg}-\mathrm{O}$.

The infrared spectrum of the $K_{\text {liq }} 3 P 10-L D H$ shows additional bands appearing at 1193 and $1100 \mathrm{~cm}^{-1}$ which could not be identified.

\subsubsection{Surface Area and $\mathrm{N}_{2}$ Adsorption-Desorption Studies}

The $\mathrm{N}_{2}$ adsorption-desorption isotherm is of type II for all samples, which is typical of mesoporous materials (Figure 4) [25]. All of the materials possessed zero micropore volume. Adsorption isotherms of this type are represented by mesoporous materials with no micropores and strong interactions between adsorbent and adsorbate molecules. This type of hysteresis loop is formed when the adsorption and desorption curves do not coincide and is caused physically by the phenomenon of capillary condensation in the mesopores.

From Figure 4, it was determined that all samples shows a horizontal course of the hysteresis branch over an appreciable range of gas uptake ( $\mathrm{p} / \mathrm{p} 0 \geq 0.6)$, while it is vertical above this ratio. This type of hysteresis loop is often observed with aggregates of plate-like particles that give rise to slit-shaped pores.

The textural properties for samples prepared by different method are gathered in Table 2. Starting from these results we can conclude that $K_{s d} 3 P 10-L D H$ presents significant textural properties. Indeed, the value of specific surface area $\left(80 \mathrm{mg} \cdot \mathrm{g}^{-1}\right)$ is near that obtained for the sample prepared by conventional method. While, $K_{l i q} 3 P 10-L D H$ prepared by method 2 has a very weak value of specific surface area.

\subsubsection{DSC Study}

The DSC curves of the $K_{l i q} 3 P 10$ and $K_{s d} 3 P 10$ hydrotalcite prepared by mechanochemical synthesis method and co-precipitation method usning kaolinite clay as aluminum 


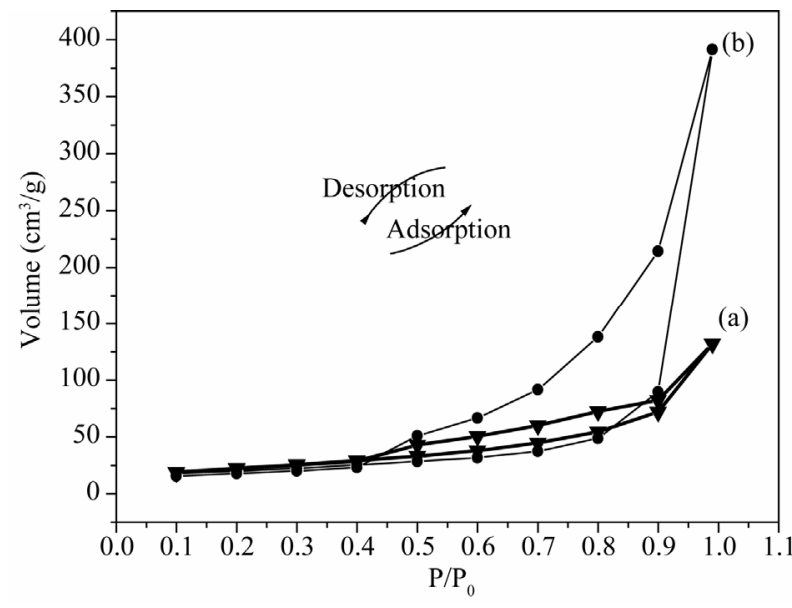

Figure 4. $\mathrm{N}_{2}$ adsorption-desorption isotherms: (a) $K_{s d} 3 P 10$ LDH; (b) $K_{\text {liq }} 3 P 10-L D H$.

Table 2. Textural properties for various sorbent samples.

\begin{tabular}{ccccccc}
\hline & \multicolumn{2}{c}{$K_{\text {sd }} P 10$} & & \multicolumn{2}{c}{$K_{\text {Liq }} P 10$} \\
\cline { 2 - 3 } \cline { 5 - 6 } & $\begin{array}{c}\mathrm{S}_{\mathrm{BET}} \\
\left(\mathrm{m}^{2} / \mathrm{g}\right)\end{array}$ & $\begin{array}{c}\mathrm{V}_{\text {macropore }} \\
\left(\mathrm{cm}^{3} / \mathrm{g}\right)\end{array}$ & & $\begin{array}{c}\mathrm{S}_{\mathrm{BET}} \\
\left(\mathrm{m}^{2} / \mathrm{g}\right)\end{array}$ & $\begin{array}{c}\mathrm{V}_{\text {macropore }} \\
\left(\mathrm{cm}^{3} / \mathrm{g}\right)\end{array}$ \\
\hline $\begin{array}{c}\text { Before } \\
\text { calcination } \\
\begin{array}{c}\text { After } \\
\text { calcination }\end{array}\end{array}$ & 80 & 0.2044 & & 78 & 0.6052 \\
\hline
\end{tabular}

source are shown in Figure 5. Both the DSC profiles exhibited two apparent endothermic events during the thermal decomposition. The first event is at $200^{\circ} \mathrm{C}$ for $K_{s d} 3 P 10$ and at $198^{\circ} \mathrm{C}$ for $K_{\text {liq }} 3 P 10$, the second thermal event is at $410^{\circ} \mathrm{C}$ for $K_{s d} 3 P 10$ and at $361^{\circ} \mathrm{C}$ for $K_{\text {liq }} 3 P 10$. In the first decomposition stage, the crystal water released. And in the second decomposition stage, the hydroxyl $\left(\mathrm{OH}^{-}\right)$octahedral structure is destroyed; the hydroxyl $\left(\mathrm{OH}^{-}\right)$and gas of $\mathrm{H}_{2} \mathrm{O}$ and $\mathrm{CO}_{3}^{2-}$ anion release, and $\mathrm{CO}_{2}, \mathrm{MgO}$ and $\mathrm{Al}_{2} \mathrm{O}_{3}$ are formed. The second thermal event for $K_{s d} 3 P 10\left(410^{\circ} \mathrm{C}\right)$ which more larger than for $K_{\text {liq }} 3 P 10\left(361^{\circ} \mathrm{C}\right)$ indicated that the sample prepared by kaolinite clay in natural solid state possessed high thermal stability, this observation can be explained by the presence of $\mathrm{SO}_{2}$ in the sample.

\subsubsection{Memory Effect of Calcined $K_{\text {liq }} 3 P 10$ and $K_{s d} 3 P 10$ Hydrotalcite}

The most important characteristic of layered double hydroxides is their ability to reconstruct themselves to their original structure. It has already been reported that $\mathrm{Mg}-\mathrm{Al}$ hydrotalcites can be reconstructed when the samples are calcined below the temperature at which spinel formation does not take place. Figures $\mathbf{6}$ and $\mathbf{7}$ show the XRD pattern of samples calcined at $500^{\circ} \mathrm{C}$. From the pattern it was observed that the layered structure was

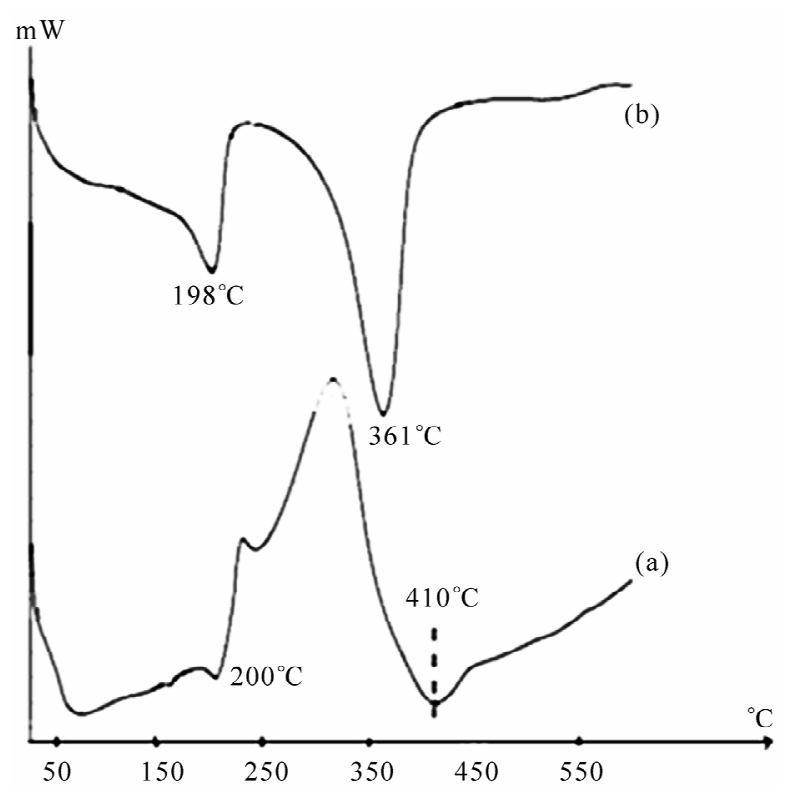

Figure 5. DSC curves of: (a) $K_{s d} 3 P 10-L D H$; (b) $K_{\text {liq }} 3 P 10-$ LDH.

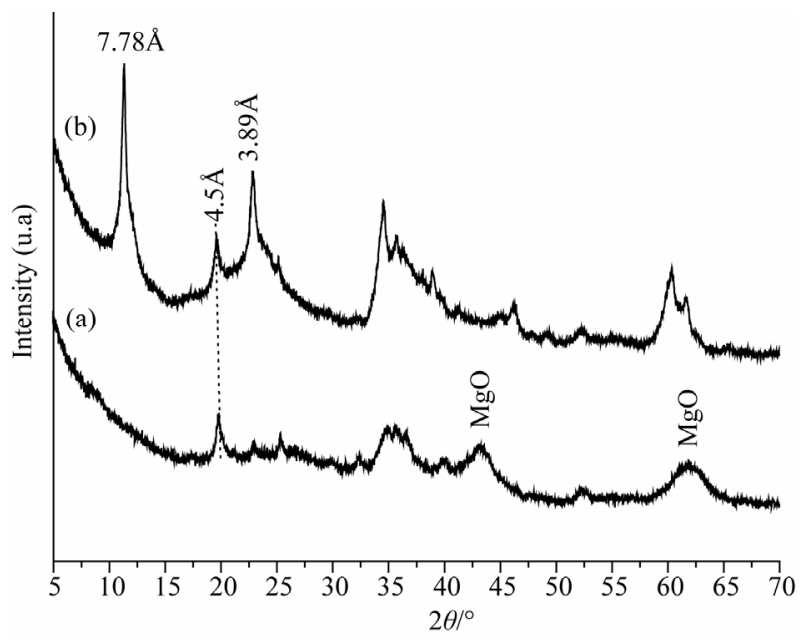

Figure 6. Powder XRD patterns of $K_{s d} 3 P 10-L D H$ (a) calcined in air at $500^{\circ} \mathrm{C}$; (b) calcined at $500^{\circ} \mathrm{C}$ and treated in water for 2 days for reconstruction.

completely destroyed, which is clearly indicated by the disappearance of the (003) and (006) peaks at lower $2 \theta$ values in the original material (Figures 1(c) and 1(d)).

For $K_{s d} 3 P 10-L D H$, the Figure 6(a) shows the presence of a peak at $4.5 \AA$ due argillaceous phase, which is present as an impure phase, along with peaks due to $\mathrm{MgO}$. To find out whether the hydrotalcite synthesized from the natural clay could be reconstructed to its original structure, the $K_{s d} 3 P 10-L D H$ and $K_{\text {liq }} 3 P 10-L D H$ samples, which were previously calcined at $500^{\circ} \mathrm{C}$, was put in water for 2 days. As shown in Figure 6(b) and Figure 7(b), the materials were completely reconstructed to its 


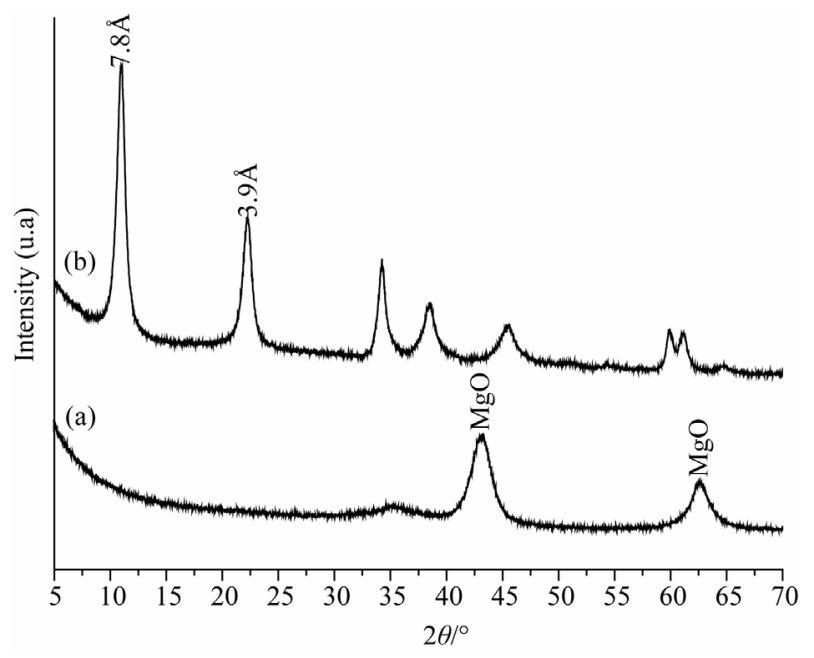

Figure 7. Powder XRD patterns of $K_{\text {liq }} 3 P 10-L D H$ (a) calcined in air at $500^{\circ} \mathrm{C}$; (b) calcined at $500^{\circ} \mathrm{C}$ and treated in water for 2 days for reconstruction.

original layered structure, as indicated by the appearance of the (003) and (006) peaks.

\subsection{The Optimisation of the Operating Conditions of Synthesis}

\subsubsection{The Effect of $\mathrm{Mg}^{2+} / \mathrm{Al}^{3+}$ Molar Ratio}

The XRD patterns of samples prepared by method 1 at different $\mathrm{Mg}^{2+} / \mathrm{Al}^{3+}$ molar ratio show that no hydrotalcite structure was formed when $\mathrm{R}<3$. From Figure 8, well-crystalline $\mathrm{LDH}$ was obtained for $\mathrm{Mg}^{2+} / \mathrm{Al}^{3+}=3.0$.

From Figure 9, it was determined that as the $\mathrm{Mg}^{2+}$ $\mathrm{Al}^{3+}$ molar ratio increases, from 0.5 to 4 , the intensity of 003 and 006 reflections increases, are corresponding to an increase of the formation of the LDH structure. Well-crystalline LDH was obtained for $\mathrm{Mg}^{2+} / \mathrm{Al}^{3+}=1.0$ (Figure 9) belong $\mathrm{R}=1$, the intensity of 003 and 006 reflections decreases corresponding to the decreasing in cristallinity.

\subsubsection{The Effect of of $\mathbf{p H}$ of Synthesis}

The $\mathrm{pH}$ of preparation is important in the formation of all hydrotalcite-type materials and the optimum $\mathrm{pH}$ depends on the cations used. From Figure 10, it was determined that samples prepared by method 1 and at $\mathrm{pH}=8$ displayed very weak, broad reflections at $2 \theta$ value of $11^{\circ}$ compared to $K_{s d} 3 P 10-L D H$ and $K_{s d} 3 P 12-L D H$ prepared at $\mathrm{pH}=10$ and 12 respectively (Figure 10). The XRD patterns of $K_{s d} 3 P 8(\mathrm{pH}=8)$ show that no hydrotalcite structure was formed under these synthesis conditions. The broadness of the reflections indicates that the sample was poorly crystalline; brucite was formed instead of hydrotalcite. Samples prepared within the $\mathrm{pH}$ range of 10 12 show patterns similar to that of hydrotalcite. The difference between these samples is in the intensity of the

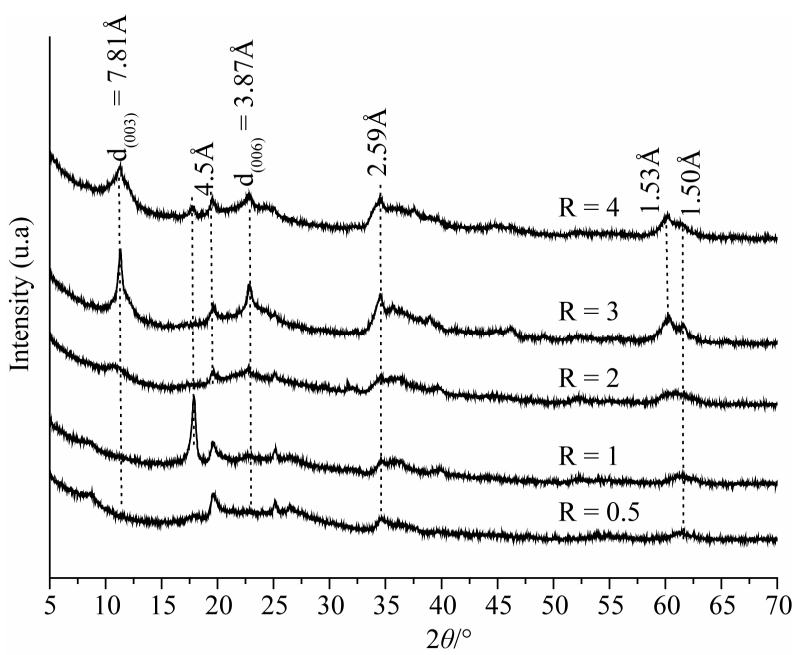

Figure.8. X-ray patterns of clay sample synthesized by method 1 at different $\mathrm{Mg}^{2+} / \mathrm{Al}^{3+}$ molar ratio.

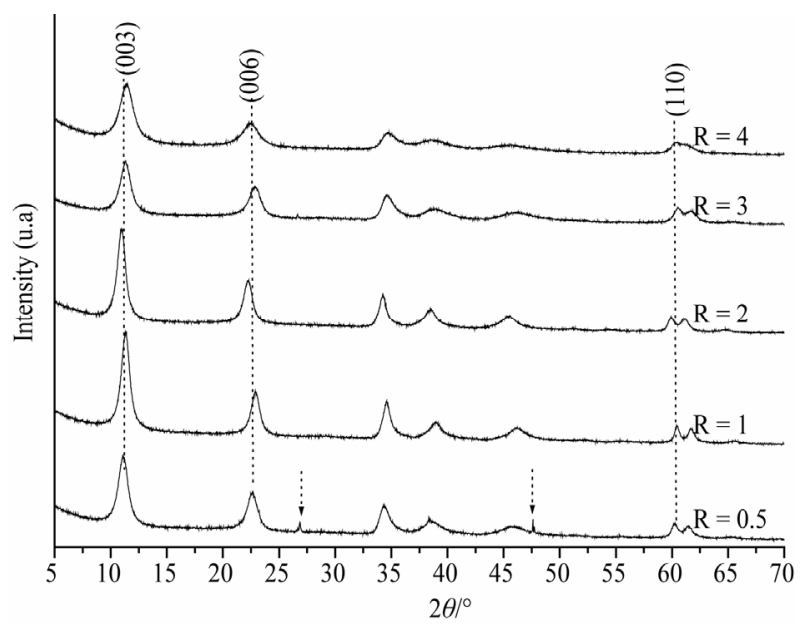

Figure 9. X-ray patterns of clay sample synthesized by method 2 at different $R\left(R=M^{2+} / \mathbf{A l}^{3+}\right.$ molar ratio).

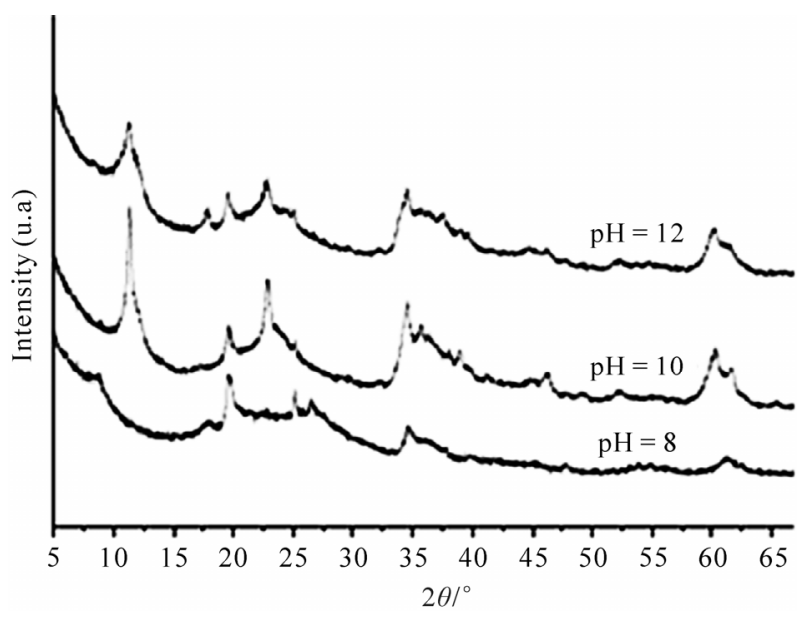

Figure 10. X-ray patterns of clay sample synthesized by method 1 at different $\mathrm{pH}$. 


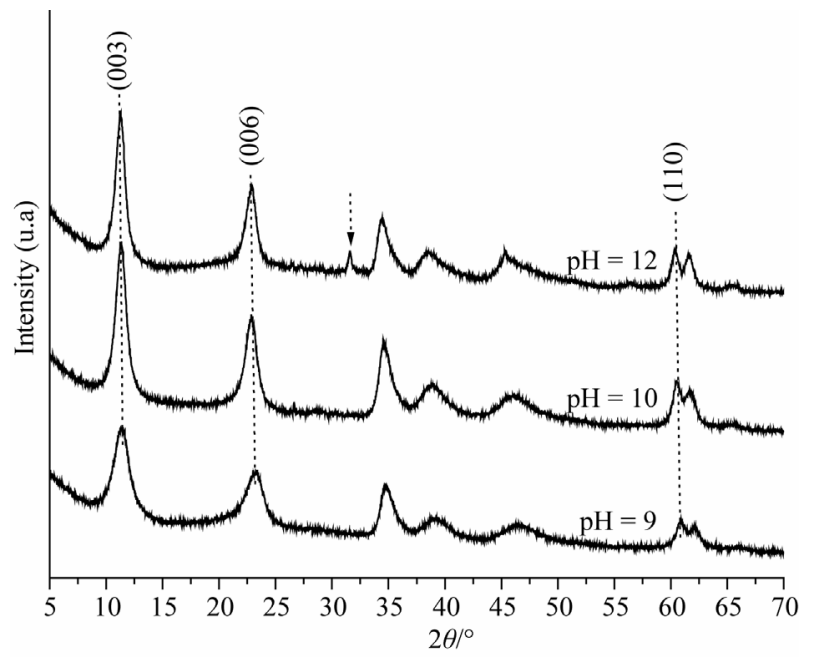

Figure 11. X-ray patterns of clay sample synthesized by method 2 at different $\mathrm{pH}$.

(001) reflections. $K_{s d} 3 P 10$ have the most intense and sharpest reflections, and thus are the most crystalline samples.

Samples prepared by method 2 and at $\mathrm{pH}=9$ displayed very weak, broad reflections at $2 \theta$ value of $11^{\circ}$ The broadness of the reflections indicates that the sample was poorly crystalline. Samples prepared within the $\mathrm{pH}$ range of 10 - 12 show patterns similar to that of hydrotalcite. The difference between these samples is in the intensity of the $(00 l)$ reflections. The $K_{\text {liq }} 3 P 10$ has the most intense and sharpest reflections. $K_{\text {liq }} 3 P 12(\mathrm{pH}=12)$ shows a structure different from the previous samples; it was contaminated with $\mathrm{Al}(\mathrm{OH})_{2}$.

\section{Conclusions}

Pure and well-crystalline phases of $\mathrm{Mg}-\mathrm{Al}-\mathrm{CO}_{3} \mathrm{LDH}$ can be prepared by coprecipitation and by mechano-chemical synthesis method from the cationic clay (the kaolinite) using an aqueous solution of $\mathrm{Na}_{2} \mathrm{CO}_{3}$ as a precipitant.

The $\mathrm{pH}$ of preparation was an important factor. At $\mathrm{pH}=10$ well-crystalline LDH was formed. Below this value, the crystallinity of the LDH decreased. Strong alkaline conditions seem no favourable for the synthesis. The optimum values of $\mathrm{Mg}^{2+} / \mathrm{Al}^{3+}$ molar ratio depend of the method of synthesize. It was about 3 for synthesize by the method 1 and about 1 for the method 2. Below these ratios poorly crystalline products were obtained.

\section{REFERENCES}

[1] H. F. W. Taylor, "Crystal Structures of Some Double Hydroxide Minerals," Mineralogical Magazine, Vol. 39, 1973, pp. 377- 389. doi:10.1180/minmag.1973.039.304.01

[2] S. Miyata, "The Syntheses of Hydrotalcite-Like Compounds and Their Structures and Physico-Chemical Prop- erties I: The Systems $\mathrm{Mg}^{2+}-\mathrm{Al}^{3+}-\mathrm{NO}_{3}^{-}, \mathrm{Mg}^{2+}-\mathrm{Al}^{3+}-\mathrm{Cl}^{-}$, $\mathrm{Mg}^{2+}-\mathrm{Al}^{3+}-\mathrm{ClO}_{4}^{-}, \mathrm{Ni}^{2+}-\mathrm{Al}^{3+}-\mathrm{Cl}^{-}$and $\mathrm{Zn}^{2+}-\mathrm{Al}^{3+}-\mathrm{Cl}^{-}$,". Clays Clay Miner, Vol. 23, 1975, pp. 369-375. doi:10.1346/CCMN.1975.0230508

[3] M. Bellotto, B. Rebours, O. Clause, J. Lynch, D. Bazin and E. Elkaim, "Hydrotalcite Decomposition Mechanism: A Clue to the Structure and Reactivity of Spinel-Like Mixed Oxides," The Journal of Physical Chemistry, Vol. 100, No. 20, 1996, pp. 8535-8542. doi:10.1021/jp960040i

[4] F. Cavani, F. Trifiro and A. Vaccari, "Hydrotalcite-Type Anionic Clays: Preparation, Properties and Applications," Catalysis Today, Vol. 11, No. 2, 1991, pp. 173-301. doi:10.1016/0920-5861(91)80068-K

[5] A. De Roy and J. P. Besse, "Conductivité Ionique de Composés de Type Hydrotalcite," Solid State Ionics, Vol. 35, No. 1-2, 1989, pp. 35-43. doi:10.1016/0167-2738(89)90009-X

[6] J. E. Moneyron, A. De Roy and J. P. Besse, "Realization of a Humidity Sensor," Sensors and Actuators B: Chemical, Vol. 4, No. 1-2, 1991, pp. 189-194. doi:10.1016/0925-4005(91)80197-R

[7] G. Carja and G. Delahay, "Mesoporous Mixed Oxides Derived from Pillared Oxovanadates Layered Double hyDroxides as New Catalysts for the Selective Catalytic Reduction of $\mathrm{NO}$ by $\mathrm{NH}_{3}$," Applied Catalysis B: Environmental, Vol. 47, No. 1, 2004, pp. 59-66. doi:10.1016/j.apcatb.2003.07.004

[8] H. Schaper, J. J. Berg-Slot and W. H. J. Stork, "Stabilized Magnesia: A Novel Catalyst (Support) Material," Applied Catalysis, Vol. 54, No. 1, 1989, pp. 79-90. doi:10.1016/S0166-9834(00)82356-8

[9] P. C. Pavan, G. D. Gomes and J. B. Valim, “Adsorption of Sodium Dodecyl Sulfate on Layered Double Hydroxides," Microporous and Mesoporous Materials, Vol. 21, No. 4-6, 1998, pp. 659-665. doi:10.1016/S1387-1811(98)00054-7

[10] P. C. Pavan, E. L. Crepaldi, G. D. Gomes and J. B. Valim, "Adsorption of Sodium Dodecylsulfate on a Hydrotal-Cite-Like Compound. Effect of Temperature, $\mathrm{pH}$ and Ionic Strength," Colloids and Surfaces A, Vol. 154, No. 3, 1999, pp. 399-410. doi:10.1016/S0927-7757(98)00847-4

[11] M. Meyn, K. Beneke and G. Lagaly, "Anion-Exchange Reactions of Layered Double Hydroxides," Inorganic Chemistry, Vol. 29, No. 26, 1990, pp. 5201-5207. doi:10.1021/ic00351a013

[12] J. H. Choy, S. Y. Kwak, J. S. Park, Y. J. Jeong and J. Portier, "Intercalative Nanohybrids of Nucleoside Monophos-Phates and DNA in Layered Metal Hydroxide," Journal of the American Chemical Society, Vol. 121, No. 6, 1999, pp. 1399-1400. doi:10.1021/ja981823f

[13] J. H. Choy, J. S. Jung, J. M. Oh, M. Park, J. Jeong, Y. K. Kang and O. J. Han, "Layered Double Hydroxide as an Efficient Drug Reservoir for Folate Derivatives," Biomaterals, Vol. 25, No. 15, 2004, pp. 3059-3064. doi:10.1016/j.biomaterials.2003.09.083

[14] M. Valcheva-Traykova, V. Davidova and A. Weiss, "Thermal Decomposition of Mg, Al-Hydrotalcite Mate- 
rial," Journal of Materials Science, Vol. 28, 1983, pp. 2157-2162. doi:10.1007/BF00367577

[15] M. Del Acro, P. Del Malet, R. Trujillano and R. Rives,. "Synthesis and Characterization of Hydrotalcites Containing $\mathrm{Ni}(\mathrm{II})$ and $\mathrm{Fe}(\mathrm{III})$ and Their Calcination Products," Journal of Chemistry of. Materials, Vol. 11, No. 3, 1999, pp. 624-633. doi:10.1021/cm9804923

[16] X. Hou and J. R. Kirkpatrick, "Thermal Evolution of the $\mathrm{Cl}-\mathrm{LiAl}_{2}$ Layered Double Hydroxide: A Multinuclear MAS NMR and XRD Perspective," Inorganic Chemistry, Vol. 40, No. 25, 2001, pp. 6397-6404. doi:10.1021/ic010671d

[17] P. Beaudot, M. E. De Roy and J.-P. Besse, "Intercalation of Platinum Complex in LDH Compounds," Journal of Solid State Chemistry, Vol. 161, No. 2, 2001, pp. 332-340. doi:10.1006/jssc.2001.9322

[18] Y. Seida and Y. Nakano, "Removal of Phosphate by Layered Double Hydroxide Containing Iron," Water Research, Vol. 36, No. 5, 2002, pp. 1306-1312. doi:10.1016/S0043-1354(01)00340-2

[19] G. Brindley and G. Brown, "Crystal Structures of Clay Minerals and their X-Ray Identification," Mineralogical Society, London, 1984

[20] A. De Roy, C. Forano, K. El Malki and J.-P. Besse, "Anionic Clays: Trends in Pillaring Chemistry," In: M. L. Occelli and H. E. Robson, Eds., Synthesis of Microporous
Materials, Van Nostrand Reinhold, New York, 1992, pp. 108-169.

[21] J. Das, D. Das and K.M., Parida, "Preparation and Characterization of Mg-Al Hydrotalcite-Like Compounds Containing Cerium," Journal of Colloid and Interface Science, Vol. 301, No. 2, 2006, pp. 569-574. doi:10.1016/j.jcis.2006.05.014

[22] G. Allegra and G. Ronca, "Crystal Powder Statistics. II. Line Profiles in Diffraction Spectra of Identical Crystals and of Gaussian Samples. Crystal Size Distributions," Acta Crystallographica Section A, Vol. 34, part 6, 1978, pp. 1006-1013.

[23] E. Alvarez-Ayuso and H. W. "Nugteren. Purification of Chromium (VI) Finishing Wastewaters Using Calcined and Uncalcined $\mathrm{Mg}$-Al- $\mathrm{CO}_{3}$-Hydrotalcite," Journal of Water Research, Vol. 39, No. 12, 2005, pp. 2535-2542. doi:10.1016/j.watres.2005.04.069

[24] J. T. Kloprogge, D. Wharton, L. Hickey and R. L. Frost, "Infrared and Raman Study of Interlayer Anions $\mathrm{CO}_{3}^{2-}$, $\mathrm{NO}_{3}^{-}, \mathrm{SO}_{4}^{2-}$ and $\mathrm{ClO}_{4}^{-}$in $\mathrm{Mg} / \mathrm{Al}-\mathrm{Hydrotal}$ cite," Journal of American Mineralogist, Vol. 87, 2002, pp. 623629.

[25] S. J. Gregg and K. S. W. Sing, "Adsorption, Surface Area and Porosity," 2nd Edition, Academic Press, London, 1982. 